\title{
KUALITAS LAYANAN DAN KEPERCAYAAN TERHADAP KEPUASAN PENGGUNA JASA PENYEBERANGAN PADA KAPAL MOTOR PENUMPANG PRATHITA PT ASDP INDONESIA FERRY (PERSERO) CABANG KETAPANG DI BANYUWANGI
}

\author{
${ }^{1)}$ Bambang Suryantoro \\ ${ }^{2)}$ Rizky Resmito Adi Prasongko \\ ${ }^{1)}$ STIE Kasih Bangsa Jakarta \\ ${ }^{2)}$ STIA dan Manajemen Kepelabuhan Barunawati Surabaya \\ 1) mbangsur17@gmail.com
}

\begin{abstract}
Abstrak
Tujuan pada penelitian ini adalah untuk mengetahui pengaruh kualitas layanan dan kepercayaan terhadap kepuasan pengguna jasa penyeberangan pada Kapal Motor Penumpang Prathita PT. ASDP Indonesia Ferry (Persero) Cabang Ketapang. Data yang digunakan dalam penelitian ini adalah data primer yang diperoleh dengan menyebarkan kuesioner kepada pengguna jasa penyeberangan pada Kapal Motor Penumpang Prathita PT. ASDP Indonesia Ferry (Persero) Cabang Ketapang berjumlah 100 orang. Dengan menggunakan teknik analisis regresi linier berganda. Hasil pengujian menunjukkan $R$ Square sebesar 0,632 hal ini menunjukkan 63,2\% kepuasan pengguna jasa penyeberangan pada KMP. Prathita dijelaskan oleh variabel kualitas layanan dan kepercayaan dan sisanya sebanyak 36,8\% dipengaruhi oleh variabel lain diluar penelitian. Variabel kualitas layanan dan kepercayaan secara parsial berpengaruh signifikan terhadap kepuasan konsumen diterima yaitu dengan tingkat signifikansi masing-masing kurang dari 0,05. Selain itu hasil korelasi parsial menunjukkan ada pengaruh secara parsial kualitas layanan dan kepercayaan terhadap kepuasan konsumen yairu kualitas layanan sebesar $57,0 \%$ dan kepercayaan $\left(\mathrm{X}_{2}\right)$ sebesar $66,4 \%$
\end{abstract}

Kata kunci: Kualitas Layanan, Kepercayaan, Kepuasan Konsumen

\section{PENDAHULUAN}

PT ASDP Indonesia Ferry (Persero) adalah perusahaan BUMN yang mengelola pelabuhan penyeberangan di seluruh Indonesia. PT ASDP Indonesia Ferry (Persero) cabang Ketapang Banyuwangi terus berupaya meningkatkan pelayanannya baik di dermaga maupun di armadanya yaitu KMP (Kapal Motor Penumpang) Prathita dan KMP Mutis, armada tersebut kini hanya sisa satu karena kebutuhan operasional yaitu KMP Prathita. KMP Prahita yang memiliki GT 507 gross tonnage ini pernah kandas di perairan Selat Bali saat akan bersandar di Pelabuhan ASDP Gilimanuk, Jembrana, Bali. Kapal itu berlayar dari Pelabuhan Ketapang, Banyuwangi. Kapal kandas sekitar pukul 02.00 WIB akibat arus yang kencang dari selatan sehingga kapal terseret ke utara. Hal ini tentunya akan berpengaruh pada kepuasan pengguna jasa penyeberangan KMP Prahita ke depannya.

Berkembangnya sektor pariwisata juga sebuah fenomena yang menimbulkan semakin tingginya tingkat persaingan antara perusahaan-perusahaan di Indonesia, khususnya perusahaan jasa. Perusahaan-perusahaan jasa tersebut berlomba-lomba berusaha untuk memperkuat strategi pemasarannya. Perusahaan merasa perlu untuk mempertahankan konsumennya agar tidak berpindah ke perusahaan lain. Tidak terkecuali perusahaan dalam bidang layanan jasa yang semakin kompetitif dan menuntut untuk menggunakan sumber daya yang dimiliki dengan sebaik mungkin sehingga pengguna jasa merasa puas.Salah satunya adalah jasa penyeberangan armada kapal laut.

Secara teori kepuasan konsumen memiliki hubungan yang erat dengan kualitas. Kualitas memberikan dorongan atau motivasi kepada konsumen untuk menjalin ikatan dan hubungan yang baik dan kuat dengan penyedia jasa. Adanya ikatan dan hubungan yang kuat dengan konsumen, maka penyedia jasa sebagai perusahaan jasa dapat memahami kebutuhan konsumen dan berusaha memenuhinya serta meminimkan kesalahan yang mengakibatkan kekecewaan konsumen. Menurut Tjiptono (2013 : 30) mengemukakan ada 5 (lima) dimensi yang digunakan untuk mengukur kualitas pelayanan yaitu bukti fisik (tangibles), kehandalan (reliability), daya tanggap (responsiveness), jaminan (assurance) dan perhatian (empathy).

Menurut Irawan (2012 : 55), mengatakan bahwa antisipasi kualitas harus dilakukan oleh penyedia jasa untuk tetap bertahan dan berkembang adalah meningkatkan pelayanan kepada konsumen, karena konsumen merupakan sumber pendapatan dari penyedia jasa baik secara langsung 
maupu secara tidak langsung. Tanpa adanya konsumen, penyedia jasa tidak dapat bertahan dan berkembang. Oleh sebab itu dalam rangka meningkatkan kunjungan konsumen maka penyedia jasa harus mampu menampilkan dan memberikan kepuasan kepada konsumen. Tujuan penelitian ini untuk mengetahui pengaruh kualitas layanan dan kepercayaan berpengaruh secara simultan terhadap kepuasan pengguna jasa penyeberngan pada Kapal Motor Penumpang Prathita PT. ASDP Indonesia Ferry (Persero) Cabang Ketapang.

\section{LANDASAN TEORI DAN PENGEMBANGAN HIPOTESIS}

\section{Kualitas Layanan}

Menurut Lovelock (2014 : 229), dalam bukunya mencoba mendefinisikan "kualitas sebagai suatu tingkat atau ukuran mutu terbaik. Dalam hal ini termasuk pengontrolan variabel-variabel yang berkenaan dalam mencapai mutu yang ditetapkan untuk memenuhi permintaan konsumen". Menurut Payne (2013: 421) kualitas layanan ditentukan oleh persepsi penggunanya. Penilaian baik buruknya kualitas layanan yang diberikan oleh suatu badan usaha ditentukan oleh persepsi penggunanya, sehingga setiap badan usaha dituntut untuk dapat memberikan kualitas layanan yang sebaik-baiknya pada pelanggannya untuk membedakannya dengan badan usaha yang lainnya.

Untuk menilai suatu kualitas layanan, para pelanggan dapat menggunakan lima dimensi kualitas yang dikemukakan oleh Lupiyoadi (2014 : 148), yaitu :

1. Tangibles (bukti langsung), yaitu penampilan dari fasilitas fisik, perlengkapan, pegawai dan sarana komunikasi.

2. Reliability (keandalan), yaitu kemampuan memberikan pelayanan yang dijanjikan dengan segera, akurat dan memuaskan.

3. Responsiveness (daya tanggap), yaitu keinginan para staf untuk membantu para konsumen dan memberikan pelayanan dengan tanggap.

4. Assurance (jaminan), yaitu mencakup pengetahuan, kemampuan, kesopanan dan sifat dapat dipercaya yang dimiliki para staf.

5. Emphaty, meliputi kemudahan dalam melakukan hubungan, komunikasi yang baik, perhatian pribadi, dan memahami kebutuhan para konsumen.

\section{Kepercayaan}

Menurut Luarn dan Lin (2003) dalam Ferrinadewi (2008: 147), kepercayaan adalah sejumlah keyakinan spesifik terhadap integritas (kejujuran pihak yang dipercaya dan kemampuan menepati janji), benevolence (perhatian dan motivasi yang dipercaya untuk bertindak sesuai dengan kepentingan yang mempercayai mereka), competency (kemampuan pihak yang dipercaya untuk melaksanakan kebutuhan yang mempercayai) dan predictability (konsistensi perilaku pihak yang dipercaya). Menurut Zheng \& Dai (2013) dalam Alamsyah (2015), besarnya kepercayaan nasabah terhadap sistem elektronik berkaitan dengan besarnya kepercayaan mereka terhadap online banking. Ketika nasabah memperkirakan faktor kepercayaan, beberapa persoalan muncul dalam pikiran mereka dan salah satu persoalan tersebut adalah kesesuaian kemampuan dari sistem elektronik tersebut dengan harapan nasabah.

Menurut Hwang \& Kim (2006) dalam Alamsyah (2015), faktor yang membentuk kepercayaan seseorang terhadap yang lain ada tiga yaitu :

1. Kemampuan (ability),

Kemampuan mengacu pada kompetensi dan karakteristik penjual atau organisasi dalam mempengaruhi dan mengotorisasi wilayah yang spesifik. Dalam hal ini, bagaimana penjual mampu menyediakan, melayani, sampai mengamankan transaksi dari gangguan pihak lain. Artinya bahwa konsumen memperoleh jaminan kepuasan dan keamanan dari penjual dalam melakukan transaksi. Kim (2009) menyatakan bahwa ability meliputi kompetensi, pengalaman, pengesahan institusional, dan kemampuam dalam ilmu pengetahuan.

2. Kebaikan hati (benevolence), 
Kebaikan hati merupakan kemauan penjual dalam memberikan kepuasan yang saling menguntungkan antara dirinya dengan konsumen. Profit yang diperoleh penjual dapat dimaksimumkan, tetapi kepuasan konsumen juga tinggi. Penjual bukan semata-mata mengejar profit maksimum semata, melainkan juga memiliki perhatian yang besar dalam mewujudkan kepuasan konsumen. Menurut Kim (2009), benevolence meliputi perhatian, empati, keyakinan, dan daya terima.

3. Integritas (integrity),

Integritas berkaitan dengan bagaimana perilaku atau kebiasaan penjual dalam menjalankan bisnisnya. Informasi yang diberikan kepada konsumen apakah benar sesuai dengan fakta atau tidak. Kualitas produk yang dijual apakah dapat dipercaya atau tidak. Integrity dapat dilihat dari sudut kewajaran, pemenuhan, kesetiaan, keterusterangan, keterkaitan, dan kehandalan.

\section{Kepuasan Konsumen}

Kepuasan pelanggan disebut sebagai salah satu strategi untuk memenangkan persaingan. Secara tradisional falsafah marketing merupakan pencapaian kepuasan pelanggan. Setiap individu memiliki kebutuhan dan keinginan yang harus dipenuhi untuk mempertahankan hidupnya. Produk atau jasa dibuat untuk memenuhi apa yang dibutuhkan dan diinginkan pelanggan. Kalau hal itu sudah tercapai, berarti kepuasan pelanggan sudah terjadi dan diharapkan produsen akan mampu untuk menghasilkan barang dan jasa sesuai yang dibutuhkan dan diinginkan oleh pelanggan.

Menurut Kotler (2013: 53) bahwa "kepuasan merupakan perasaan seseorang yang timbul dari perbedaan antara kinerja (hasil) yang diterima pelanggan dengan harapannya". Jika kinerjanya lebih rendah dari harapannya, maka pelanggan kecewa. Jika kinerja sama dengan harapannya, maka pelanggan puas. Jika kinerjanya melebihi harapannya, maka pelanggan akan sangat puas. Menurut Mowen (2012 : 111) definisi kepuasan pelanggan adalah "keseluruhan sikap pelanggan setelah memperoleh dan menggunakan barang atau layanan". Kepuasan baru bisa dirasakan setelah kita melakukan pembelian dan menikmati layanan yang diberikan. Kepuasan pelanggan dapat dilihat setelah terjadi pembelian ulang dan pembelian yang direkomendasikan oleh pelanggan lama. Kepuasan pelanggan merupakan pendekatan yang penting untuk dapat mempertahankan pelanggan seperti dikemukakan oleh Kotler (2013: 48) bahwa tanpa adanya kepuasan pelanggan, maka perusahaan tersebut sulit untuk bertahan dalam menghadapi persaingan yang kompetitif, kalau pelanggan tidak terpuaskan maka akan mudah untuk pindah ke perusahaan lain yang sejenis. Maka hipotesis penelitian ini adalah:

1. Variabel kualitas layanan dan kepercayaan mempunyai pengaruh simultan terhadap kepuasan konsumen Kapal Motor Penumpang Prathita PT. ASDP Indonesia Ferry (Persero) Cabang Ketapang.

2. Variabel kualitas layanan dan kepercayaan mempunyai pengaruh parsial terhadap kepuasan konsumen Kapal Motor Penumpang Prathita PT. ASDP Indonesia Ferry (Persero) Cabang Ketapang.

3. Dari kedua variabel yang diteliti, variabel kepercayaan berpengaruh dominan terhadap kepuasan konsumen Kapal Motor Penumpang Prathita PT. ASDP Indonesia Ferry (Persero) Cabang Ketapang.

\section{METODOLOGI PENELITIAN}

Variabel dalam penelitian ini meliputi:

1. Variabel bebas (variabel independen):

a. Kualitas layanan $\left(\mathrm{X}_{1}\right)$ yaitu persepsi pelanggan tentang kelebihan dari suatu layanan, meliputi:

a. Ruangan kapal memiliki fasilitas yang memadai

b. Ketepatan waktu keberangkatan kapal 
c. Ketepatan waktu kedatangan kapal

d. Kecepat tanggapan pelayan kapal dalam melayani kebutuhan penumpang selama perjalanan

e. Jaminan keselamatan dan keamanan selama perjalanan

f. Keramahan dan kesopanan karyawan/pelayan kapal selama perjalanan

b. Kepercayaan $\left(\mathrm{X}_{2}\right)$ yaitu persepsi pelanggan tentang kelebihan dari suatu layanan, meliputi:

a. Kepercayaan bahwa Kapal Motor Penumpang Prathita menjaga komitmen dalam melayani penumpang

b. Kepercayaan bahwa Kapal Motor Penumpang Prathita memberikan manfaat pada penggunanya

c. Tarif jasa yang ditawarkan oleh Kapal Motor Penumpang Prathita relatif terjangkau

d. Tarif jasa pada Kapal Motor Penumpang Prathita sesuai dengan kualitasnya

e. Tarif jasa pada Kapal Motor Penumpang Prathita sesuai dengan manfaat yang diterima

2. Variabel terikat (variabel dependen):

Kepuasan Konsumen (Y) yaitu perasaan seseorang yang timbul dari perbedaan antara kinerja (hasil) yang diterima konsumen dengan harapannya, meliputi:

a. Konsumen merasa puas terhadap kelengkapan fasilitas yang tersedia di Kapal Motor Penumpang Prathita

b. Konsumen merasa puas terhadap layanan yang diberikan oleh Kapal Motor Penumpang Prathita

c. Konsumen merasa puas karena Kapal Motor Penumpang Prathita mampu mewujudkan permintaan konsumen

d. Kinerja Kapal Motor Penumpang Prathita sesuai dengan harapan konsumen.

Populasi dalam penelitian ini adalah seluruh penumpang Kapal Motor Penumpang Prathita. Teknik pemilihan sampelnya menggunakan Quota Sampling yaitu sampling yang diambil dengan menentukan jumlah terbanyak pada penumpang di Kapal Motor Penumpang Prathita diambil sampel sebanyak 100 penumpang. Adapun responden yang dipilih adalah pria dan wanita berusia 25 tahun keatas tanpa memperhatikan tingkat pendidikan serta pekerjaan. Skala yang digunakan adalah skala likert dengan pilihan Sangat Setuju $(\mathrm{SS})=5$; Setuju $(S)=4$; Kurang Setuju $(\mathrm{KS})=3$; Tidak Setuju $(\mathrm{TS})=2$; Sangat Tidak Setuju $(\mathrm{STS})=1$. Analisis data meliputi:

1. Uji validitas dan reliabitas

Uji validitas dan reliabilitas digunakan untuk analisis butir item kuesioner. Suatu kuesioner dinyatakan valid jika nilai probabilitas setiap item dari variabel lebih kecil dari taraf signifikansi $(\alpha) 0,05$ dan suatu konstruk atau variabel dikatakan reliabel bila nilai alpha Cronbach $>0,6$.

2. Uji normalitas, uji multikolinearitas, dan heteroskedastisitas

Uji normalitas untuk melihat apakah data tersebut memiliki distribusi normal atau tidak dapat menggunakan uji statistc non parametrik kolomagorovsmirnov uji ini digunakan untuk menguji apakah residual terdistribusi secara normal atau tidak. Jika tingkat signifikansi diatas 0,05 maka dapat disimpulkan bahwa data terdistribusi normal. Uji multikolinearitas jika nilai Tolerance lebih dari 0,100 atau nilai VIF kurang dari 10, maka hal ini menunjukkan adanya multikolonieritas sedang uji heteroskedastisitas dengan melihat jika probabilitas 36 signifikansinya di atas tingkat kepercayaan 5\%, maka dapat disimpulkan model regresi tidak mengandung heteroskedastisitas

3. Analisis regresi linier berganda

Analisis yang digunakan pada penelitian ini adalah regresi linier berganda. Uji t untuk uji secara parsial dan uji F untuk uji secara simultan. Rumus tersebut adalah sebagai berikut: 
$\mathrm{Y}=\beta \mathrm{o}+\beta_{1} \mathrm{X}_{1}+\beta_{2} \mathrm{X}_{2}+\beta_{3} \mathrm{X}_{3}+\beta_{4} \mathrm{X}_{4}+\mathrm{e}$

Keterangan :

$\mathrm{Y}=$ tindakan tidak aman

$\mathrm{X}_{1}=\quad$ komitmen dan kebijakan K3

$\mathrm{X}_{2}=$ perencanaan $\mathrm{K} 3$

$\mathrm{X}_{3}=$ pelaksanaan $\mathrm{K} 3$

$\mathrm{X}_{4}=$ pemeriksaan dan tindakan perbaikan $\mathrm{K} 3$

$\beta o=$ konstanta

$\beta_{1 \ldots . . .} \beta_{3}=\quad$ koefisien regresi

e $=$ variabel pengganggu di luar variabel bebas

\section{HASIL PENELITIAN}

Uji Validitas Data

1. Uji Validitas Kualitas Layanan

Uji Validitas Kualitas Layanan (X1)

\begin{tabular}{|c|c|c|c|}
\hline Indikator & Korelasi & Signifikan & Keterangan \\
\hline X1.1 & 0,610 & 0,000 & Valid \\
X1.2 & 0,669 & 0,000 & Valid \\
X1.3 & 0,564 & 0,000 & Valid \\
X1.4 & 0,647 & 0,000 & Valid \\
X1.5 & 0,539 & 0,000 & Valid \\
X1.6 & 0,586 & 0,000 & Valid \\
\hline
\end{tabular}

Berdasarkan tabel di atas, diketahui bahwa nilai probabilitas keenam item pembentuk kualitas layanan lebih kecil dari taraf signifikansi $(\alpha)$ 0,05, berarti keenam item tersebut valid (Ghozali, 2011: 137).

2. Uji Validitas Kepercayaan

Uji Validitas Kepercayaan (X2)

\begin{tabular}{|c|c|c|c|}
\hline Indikator & Korelasi & Signifikan & Keterangan \\
\hline X2.1 & 0,740 & 0,000 & Valid \\
X2.2 & 0,708 & 0,000 & Valid \\
X2.3 & 0,666 & 0,000 & Valid \\
X2.4 & 0,622 & 0,000 & Valid \\
X2.5 & 0,648 & 0,000 & Valid \\
\hline
\end{tabular}

Berdasarkan tabel di atas, diketahui bahwa nilai probabilitas kelima item pembentuk kepercayaan lebih kecil dari taraf signifikansi () 0,05, berarti kelima item tersebut valid (Ghozali, 2011: 137).

3. Uji Validitas Kepuasan Konsumen

Uji Validitas Kepuasan Konsumen (Y)

\begin{tabular}{|c|c|c|c|}
\hline Indikator & Korelasi & Signifikan & Keterangan \\
\hline Y.1 & 0,622 & 0,000 & Valid \\
Y.2 & 0,604 & 0,000 & Valid \\
Y.3 & 0,701 & 0,000 & Valid \\
Y.4 & 0,614 & 0,000 & Valid \\
\hline
\end{tabular}

Sumber : Data Diolah, lampiran 3
rkan tabel di atas, diketahui bahwa nilai probabilitas keempat item pembentuk kepuasan konsumen lebih kecil dari taraf signifikansi $(\alpha) 0,05$, berarti keempat item tersebut valid (Ghozali, 2011: 137).

Uji Reliabilitas Data

\begin{tabular}{|l|c|c|}
\hline \multicolumn{1}{|c|}{ Variabel } & Alpha Cronbach & Keterangan \\
\hline kualitas layanan $(\mathrm{X} 1)$ & 0,679 & Reliabel \\
\hline kepercayaan $(\mathrm{X} 2)$ & 0,642 & Reliabel \\
\hline kepuasan konsumen (Y) & 0,699 & Reliabel \\
\hline
\end{tabular}

Berdasarkan tabel di atas dapat dijelaskan sebagai berikut:

1. Nilai reliabilitas kualitas layanan sebesar 0,679 sudah reliabel karena lebih besar dari 0,60 (Ghozali, 2011: 133).

2. Nilai reliabilitas kepercayaan sebesar 0,642 sudah reliabel karena lebih besar dari 0,60 (Ghozali, 2011: 133).

3. Nilai reliabilitas kepuasan konsumen sebesar 0,699 sudah reliabel karena lebih besar dari 0,60 (Ghozali, 2011: 133). 


\section{Uji Normalitas}

Nilai Kolmogorov Smirnov Z sebesar 0,444 dengan tingkat signifikan 0,989, berarti hal itu menunjukkan bahwa model regresi terdistribusi normal karena tingkat signifikansinya $\geq 0,05$.

\section{Uji Multikolinearitas}

Hasil Uji Multikolinearitas

\begin{tabular}{|l|c|c|c|}
\hline \multicolumn{1}{|c|}{ Variabel } & Toleransi & VIF & Keterangan \\
\hline Kualitas Layanan $\left(\mathrm{X}_{1}\right)$ & 0,897 & 1,114 & Non Multikolinier \\
Kepercayaan $\left(\mathrm{X}_{2}\right)$ & 0,897 & 1,114 & Non Multikolinier \\
\hline
\end{tabular}

Berdasarkan tabel dapat dianggap tidak terjadi gejala multikolinearitas antara masing-masing variabel bebas yaitu dengan melihat nilai tolerance untuk kedua variabel bebas yang lebih besar dari 10 persen (0.1) dan nilai VIF (Variance Inflation Factor) bernilai kurang dari 10. (Ghozali, 2013:118)

\section{Uji Heterokedastisitas}

Uji Heteroskedastik diidentifikasi dengan cara menghitung pakai uji Glejser. Hasil perhitungan adalah sebagai berikut:

Uji Heteroskedastisitas Metode Geyser

\begin{tabular}{|l|c|c|}
\hline \multicolumn{1}{|c|}{ Variabel } & Signifikan & Keterangan \\
\hline Kualitas Layanan $\left(\mathrm{X}_{1}\right)$ & 0,082 & Tidak ada heteroskedastik \\
Kepercayaan $\left(\mathrm{X}_{2}\right)$ & 0,740 & Tidak ada heteroskedastik \\
\hline
\end{tabular}

Berdasarkan tabel diketahui bahwa nilai signifikansinya untuk variabel kualitas layanan dan kepercayaan lebih dari 5\%, ini berarti bahwa tidak ada hubungan kedua variabel bebas dengan nilai residunya, maka dapat disimpulkan tidak terdapat gejala heteroskedastisiitas pada penelitian ini.

\section{Hasil Analisis Regresi Berganda}

Hasil perhitungan dalam analisis ini menggunakan program SPSS for Windows release 22.0 seperti yang tercantum pada lampiran, lebih rinci dapat dijelaskan sebagai berikut:

$$
\begin{aligned}
& Y=\beta_{0}+\beta_{1} X_{1}+\beta_{2} X_{2}+e \\
& Y=0,957+0,337 X_{1}+0,412 X_{2}
\end{aligned}
$$

Dari persamaan tersebut diatas dapat dijelaskan sebagai berikut :

1. Konstanta $\left(\beta_{0}\right)$ sebesar 0,957 menunjukkan besarnya kepuasan konsumen, apabila seluruh variabel bebas tersebut sama dengan nol.

2. Koefisien regresi untuk kualitas layanan $\left(\mathrm{X}_{1}\right)$ sebesar 0,337 . Berarti jika kualitas layanan $\left(\mathrm{X}_{1}\right)$ naik sebesar 1 satuan, maka kepuasan konsumen $(\mathrm{Y})$ akan mengalami kenaikan sebesar 0,337 satuan.

3. Koefisien regresi untuk kepercayaan $\left(X_{2}\right)$ sebesar 0,412. Berarti jika kepercayaan $\left(X_{2}\right)$ naik sebesar 1 satuan, maka kepuasan konsumen (Y) akan mengalami kenaikan sebesar 0,412 satuan.

Nilai $R$ square dimana hasil perhitungan dari lampiran 3 sebesar 0,632 atau 63,2\% pengaruh kualitas layanan dan kepercayaan terhadap kepuasan konsumen sebesar $63,2 \%$, sisanya 36,8 \% dipengaruhi oleh variabel lain yang tidak terdapat dalam model. Untuk mengetahui keeratan hubungan variabel bebas dengan variabel terikat maka dapat dilihat besarnya korelasi berganda, diketahui korelasi berganda sebesar 0,795 atau 79,5\% yang berarti bahwa kualitas layanan dan kepercayaan dengan kepuasan konsumen kuat.

\section{Uji F dan Uji t}

\section{Uji F}

Hasil perhitungan menunjukkan bahwa $\mathrm{F}$ hitung sebesar 83.457. Menggunakan taraf signifikan $\alpha=$ 0,05 dan derajat kebebasan (df) pembilang adalah 2 dan penyebut adalah 97 sehingga diketahui $\mathrm{F}$ tabel 3,09. Kriteria penerimaan dan penolakan yaitu Ho ditolak bila $\mathrm{F}$ hitung $>\mathrm{F}$ tabel dan Ho diterima bila F hitung < F tabel. Karena F hitung $(83.457)>\mathrm{F}$ tabel $(3,09)$ maka Ho ditolak dan Hi 
diterima. Sehingga dapat disimpulkan bahwa kualitas layanan $\left(\mathrm{X}_{1}\right)$ dan kepercayaan $\left(\mathrm{X}_{2}\right)$ secara simultan (bersamaan) mempunyai pengaruh yang signifikan terhadap kepuasan konsumen (Y).

Uji t

a. Kualitas Layanan $\left(\mathrm{X}_{1}\right)$ Terhadap Kepuasan Konsumen (Y) dengan menggunakan taraf signifikansi sebesar $\alpha=0,05$ dan derajat kebebasan (df) $=97$, dengan menggunakan two tail test diperoleh $\mathrm{t}$ tabel sebesar 1,984.Kriteria penerimaan dan penolakan yaitu Ho diterima bila $-\mathrm{t}$ tabel $\leq \mathrm{t}$ hitung $\leq \mathrm{t}$ tabel dan Ho ditolak bila $t$ hitung $>t$ tabel atau $-t$ hitung $<-t$ tabel. Karena $t$ hitung $(6,834)>t$ tabel $(1,984)$ maka Ho ditolak dan Hi diterima. Sehingga dapat disimpulkan bahwa kualitas layanan $\left(\mathrm{X}_{1}\right)$ mempunyai pengaruh yang signifikan terhadap kepuasan konsumen. Nilai korelasi parsial untuk kualitas layanan sebesar $(0,570)$ artinya perubahan kepuasan konsumen mampu dijelaskan oleh kualitas layanan sebesar 57,0\%.

b. Kepercayaan $\left(\mathrm{X}_{2}\right)$ Terhadap Kepuasan Konsumen $(\mathrm{Y})$ dengan menggunakan taraf signifikansi sebesar $\alpha=0,05$ dan derajat kebebasan (df) $=97$, dengan menggunakan two tail test diperoleh $\mathrm{t}$ tabel sebesar 1,984. Kriteria penerimaan dan penolakan yaitu Ho diterima bila $-\mathrm{t}$ tabel $\leq \mathrm{t}$ hitung $\leq$ $\mathrm{t}$ tabel dan Ho ditolak bila $\mathrm{t}$ hitung $>\mathrm{t}$ tabel atau $-\mathrm{t}$ hitung $<-\mathrm{t}$ tabel. Karena $\mathrm{t}$ hitung $(8,756)>\mathrm{t}$ tabel $(1,984)$ maka Ho ditolak dan Hi diterima. Sehingga dapat disimpulkan bahwa kepercayaan $\left(\mathrm{X}_{2}\right)$ mempunyai pengaruh yang signifikan terhadap kepuasan konsumen. Nilai korelasi parsial untuk kepercayaan sebesar $(0,664)$ artinya perubahan kepuasan konsumen mampu dijelaskan oleh kepercayaan sebesar $66,4 \%$.

\section{PEMBAHASAN}

\section{Pengaruh Kualitas Layanan dan Kepercayaan terhadap Kepuasan Konsumen}

Hasil penelitian ini mendukung hasil penelitian Syamsi (2015) dan Rudi Ardianto (2016) bahwa layanan baik yang diberikan oleh Kapal Motor Penumpang Prathita dapat memuaskan penumpang. Berdasarkan hasil tanggapan responden (tabel 4.1) menunjukkan bahwa ruangan kapal memiliki fasilitas yang memadai (nilai rata-rata 4,030) dan keberangkatan kapa tepat waktu, demikia juga kedatangannya. Kecepatan tanggapan pelayanan kapal dalam melayani kebutuhan penumpang selama perjalanan juga dinilai cukup baik oleh penumpang dengan nilai rata-rata 4,060. Transportasi adalah suatu sistem yang terdiri dari sarana dan prasarana, layanan transportasi dengan jaminan keselamatan akan memberikan kepastian dan ketenangan bagi pelaku perjalanan atau bagi pemilik barang, sehingga kegiatan sosial ekonomi masyarakat dapat terlindungi (Lupiyoadi Rambat, 2014). Sistem transportasi meliputi sub sistem prasarana berupa jalur dan simpul tempat pergerakan dan sub sistem pengendalian atau pengaturan yang memungkinkan pergerakan dilakukan secara efektif dan efisien. Melihat luasnya peranan transportasi, maka penanganan transportasi dianggap perlu dalam proses perencanaan transportasi yang lebih baik, penyediaan maupun pengelolaannya. Seiring dengan perkembangan waktu dan tuntutan kebutuhan masyarakat, maka pengelola pelabuhan perlu menyiapkan sarana dan prasarana yang mampu memberikan pelayanan sesua dengan standar yang telah ditetapkan. Oleh karena itu penting untuk menjalin kerjasama dengan instansi terkait seperti pemerintah daerah agar terjalin sinergi sehingga pelayanan dari hulu ke hilir dapat terlaksana secara efektif dan efisien (Rudi Ardianto, 2016). Nilai koefisien determinasi ( $R$ Square) yaitu sebesar 0,632, ini menunjukkan bahwa besarnya kontribusi antara variabel bebas yaitu kualitas layanan $\left(\mathrm{X}_{1}\right)$ dan kepercayaan $\left(\mathrm{X}_{2}\right)$ secara simultan menjelaskan perubahan variasi dari variabel terikat kepuasan konsumen (Y) sebesar 63,2\% sedangkan sisanya sebesar 36,8 \% dijelaskan oleh variabel lain.

\section{Pengaruh Kepercayaan terhadap Kepuasan Konsumen}

Hasil penelitian ini mendukung hasil penelitian Syamsi (2015) dan Rudi Ardianto (2016) bahwa layanan baik yang diberikan oleh Kapal Motor Penumpang Prathita dapat memuaskan penumpang. Berdasarkan hasil tanggapan responden (tabel 4.2) menunjukkan penumpang percaya bahwa Kapal Motor Penumpang Prathita menjaga komitmen dalam melayani penumpang (nilai ratarata 3,830). Penumpang percaya bahwa Kapal Motor Penumpang Prathita memberikan manfaat pada 
penggunanya. Setiap penyedia jasa akan terus menerus berusaha untuk meningkatkan kinerjanya demi tercapainya standar kualitas pelayanan yang maksimal untuk mempertahankan pelanggannya. Karena sudah tentu setiap pengguna jasa menginginkan memperoleh pelayanan yang diinginkan agar tetap menggunakan jasa layanan yang bersangkutan. Kepuasan adalah tingkat perasaan seseorang setelah membandingkan kinerja yang dirasakan dibanding dengan harapannya (Kotler, Philip, 2013)

\section{Pengaruh Dominan}

Diantara kualitas layanan $\left(\mathrm{X}_{1}\right)$ dan kepercayaan $\left(\mathrm{X}_{2}\right)$ yang mempunyai pengaruh dominan terhadap kepuasan konsumen adalah kepercayaan $\left(\mathrm{X}_{2}\right)$, hal ini karena nilai correlation partial yang berada pada tabel coefficients sebesar 66,4 \% lebih besar dari nilai correlation partial variabel kepuasan yang nilainya sebesar $57 \%$. Sehingga dapat disimpulkan bahwa variabel kepercayaan $\left(\mathrm{X}_{2}\right)$ mempunyai pengaruh yang paling dominan terhadap variabel terikat kepuasan konsumen (Y).

\section{KESIMPULAN DAN SARAN}

Kesimpulan hasil penelitian ini adalah:

1. Berdasarkan hasil $\mathrm{F}$ hitung diketahui bahwa terdapat pengaruh secara simultan antara variabel kualitas layanan $\left(\mathrm{X}_{1}\right)$ dan kepercayaan $\left(\mathrm{X}_{2}\right)$ terhadap kepuasan konsumen.

2. Berdasarkan hasil t hitung pada setiap variabel diketahui bahwa terdapat pengaruh secara parsial antara variabel kualitas layanan $\left(\mathrm{X}_{1}\right)$ dan kepercayaan $\left(\mathrm{X}_{2}\right)$ terhadap kepuasan konsumen.

3. Berdasarkan hasil korelasi parsial diketahui bahwa kepercayaan $\left(\mathrm{X}_{2}\right)$ berpengaruh dominan terhadap kepuasan konsumen (Y).

Berdasarkan uraian di atas, maka dapat dikemukakan beberapa saran yang kiranya dapat dijadikan bahan pertimbangan bagi perusahaan, antara lain:

1. Penambahan petugas yang ada didalam Kapal. Petugas yang berada didalam kapal jumlahnya tidak cukup banyak. Hal ini berbanding kebalik dengan jumlah penumpang yang cukup banyak. Untuk itu pihak PT ASDP Indonesia cabang Ketapang diharapkan mampu menambah jumlah petugas didalam kapal agar jika penumpang membutuhkan segalal sesuatunya petugas siap kapan saja.

2. Perluasan areal parkir di luar pelabuhan. Sejauh ini areal parkir yang ada di didalam Pelabuhan Ketapang masih belum mencukupi kebutuhan pada saat musim liburan. Dimana jumlah penumpang yang akan menyebrang tidak sebanding dengan jumlah armada yg tersedia. Akibatnya terjadi lonjakan penumpang, lonjakan penumpang ini menimbulkan kepadatan didalam maupun luar areal pelabuhan.

3. Perlu dilakukan peningkatan dalam penjagaan dalam pengangkutan barang maupun penumpang kapal dari PT. ASDP Indonesia Ferry (Persero) agar dapat meminilaisir kerusakan barang dalam proses pengangkutan yang disebabkan oleh kelebihan tumpukan barang dalam kapal.

4. Sebaiknya PT. ASDP Indonesia Ferry (Persero) lebih mempermudah proses pengkaliman ganti rugi apabila terjadi kecelakaan ataupun kerusakan barang maupun penumpang pada pengguna jasa kapal tersebut.

5. Untuk meningkatan kepercayaan penumpang atas keselamatannya dilakukan peningkatan pengawasan baik terhadap penumpang maupun kelayakan kapal direspon oleh kesahbandaran atau otoritas pelabuhan penyeberangan (OPP). Diinstruksikan semua OPP dimasing-masing daerah memperketat pengawasan kapal dan fasilitas pelabuhan untuk kenyamanan dan keselamatan penumpang.

\section{DAFTAR PUSTAKA}

Assael, Henry. 2014. Consumer Behavior and Marketing Action, By PWS KENT Publishing Company, Fourth Edition, Boston.

Engel and Blackwell, Miniard. 2012. Perilaku Konsumen. Edisi 6. Jilid 2. Penerbit Binarupa Aksara. 
Ferrinadewi, Erna. 2008. Merek dan Psikologi Konsumen (Implikasi pada Strategi Pemasaran). Yogyakarta : PT.Graha Ilmu.

Ghozali, Imam. 2011. Aplikasi Analisis Multivariate Dengan Program SPSS. Badan Peneliti Universitas Diponegoro.

Herawati, Jajuk dan Prayekti. "Pengaruh Internet Banking Service Quality dan Kepercayaan Nasabah Terhadap Kepuasan Nasabah (Penelitian Empiris terhadap Nasabah Internet Banking di Kota Yogyakarta”. Jurnal Amenika UPY, Vol 8, hal 1-19. 2011.

Kim J., B.Jin, J.L. Swinney. "The Role of Etail Quality, Esatisfaction and Etrust in Online Loyalty Development Process", Journal of Retailing and Customer Services, Vol 16, Issue 4. 2009.

Kotler, Philip. 2013. Dasar-Dasar Pemasaran. Terjemahan. Edisi 3. Jilid I. Jakarta: Intermedia.

Kotler, Philip dan K.L. Keller. 2013. Manajemen Pemasaran. Edisi 13. Jakarta : Erlangga.

Lovelock, Christopher. 2014. Service Marketing, New York: Prentice Hall Inc.

Lupiyoadi, Rambat. 2014. Manajemen Pemasaran Jasa Teori Dan Praktik. Penerbit Salemba Empat.

Mowen John C,. 2012. Consumer Behavior. Prentice Hall Inc., Fourth Edition, Englewood Cliffs, New Jersey.

Nitisemito, Alex S. 2013. Marketing. Cetakan ke-6. Jakarta: Penerbit Ghalia Indonesia. 